\begin{tabular}{cc|c}
\hline Tar. Bil. Der. & Journal of Agricultural Sciences \\
& $\begin{array}{c}\text { Dergi web sayfası: } \\
\text { www.agri.ankara.edu.tr/dergi }\end{array}$ & Journal homepage: \\
& www.agri.ankara.edu.tr/journal
\end{tabular}

\title{
Seasonal Carbohydrate Changes in the Leaves of Some Satsuma Cultivars on Different Rootstocks
}

\author{
Ercan YILDIZ ${ }^{a}$, Mustafa KAPLANKIRAN ${ }^{\mathrm{b}}$, Turan Hakan DEMİRESER ${ }^{\mathrm{b}}$, Celil TOPLU $^{\mathrm{b}}$ \\ ${ }^{a}$ Uşak University, Faculty of Agriculture and Natural Sciences, Department of Horticulture, Uşak, TURKEY \\ ${ }^{b}$ Mustafa Kemal University, Faculty of Agriculture, Department of Horticulture, Antakya, Hatay, TURKEY
}

\section{ARTICLE INFO}

Research Article

DOI: 10.15832 /ankutbd.447710

Corresponding Author: Ercan YILDIZ, E-mail: ercanyildiz54@gmail.com, Tel: +90 (276) 2212200 Received: 16 December 2014, Received in Revised Form: 19 February 2016, Accepted: 19 February 2016

\begin{abstract}
The seasonal changes of carbohydrate content were monitored in the leaves of 'Okitsu', 'Clausellina', and 'Silverhill' satsuma cultivars budded on the sour orange (Citrus aurantium L. var. Yerli), Carrizo and Troyer citranges (Poncirus trifoliata Raf. x Citrus sinensis Osb. var. Troyer and Carrizo) during the 2010 and 2011 seasons. The seasonal changing trends of leaf soluble sugar contents of 3 satsuma cultivars budded on different rootstocks were similar. The sucrose was the most abundant soluble sugar. Carbohydrate contents had a maximum level at dormant period, and remained at low level during summer. In this period, the sharp decrease in leaf total carbohydrate concentration of 'Okitsu', 'Clausellina' and 'Silverhill' occurred in April with a rate of 27.9\%, 22.6\% and 21.0\%, respectively. Accumulation of carbohydrate in leaves generally started after mid summer and continued until the end of year. The rootstocks were found to be not significant for total soluble sugar, starch and total carbohydrate concentration in most of the months. The cultivars had a significant effect on carbohydrate fractions of leaves compared to rootstocks. The scion-rootstock combination was significant on total carbohydrate concentration of leaves in all months investigated.
\end{abstract}

Keywords: Satsuma; Cultivar; Rootstock; Non-structural carbohydrates; Leaf tissue

\section{Farklı Anaçlar Üzerine Aşılı Bazı Satsuma Çeşitlerinin Yapraklarında Karbonhidrat Fraksiyonlarının Değişimi}

\section{ESER BİLGİSI}

Araştırma Makalesi

Sorumlu Yazar: Ercan YILDIZ, E-posta: ercanyildiz54@gmail.com, Tel: +90 (276) 2212200

Geliş Tarihi: 16 Aralık 2014, Düzeltmelerin Gelişi: 19 Şubat 2016, Kabul: 19 Şubat 2016

\section{ÖZET}

2010 ve 2011 yıllarında 'Okitsu', 'Clausellina' ve 'Silverhill' satsuma çeşitlerinin yapraklarındaki karbonhidrat içeriklerinin mevsimsel değişimi üzerine Troyer ve Carrizo sitranjları (Poncirus trifoliata Raf. x Citrus sinensis Osb. var. Troyer ve Carrizo) ile Yerli turunç (Citrus aurantium L. var. "common") anacının etkisi ortaya konmuştur. Farklı anaçlar üzerine aşılı 3 satsuma çeşidinin karbonhidrat içeriklerinin mevsimsel değişimi birbirlerine benzer olmuştur. 
Sakaroz yapraklarda en baskın indirgen şeker olarak belirlenmiştir. Yaprakların karbonhidrat içerikleri dinlenme döneminde maksimum seviyelerde iken, Yaz periyodunda düşük seviyelerde yer almıştır. 'Okitsu', 'Clausellina' ve 'Silverhill' çeşitlerinde yaprakların toplam karbonhidrat içerikleri nisan ayında çeşitlere göre sırasılla \% 27.9, \% 22.6 ve \% 21.0 oranlarında keskin bir azalma göstermiştir. Yapraklarda karbonhidrat birikimi genellikle yaz ortasından sonra başlamış ve bu durum yılsonuna kadar devam etmiştir. Anaçlar arasında toplam şeker, nişasta ve toplam karbonhidrat içeriğindeki farklılıklar çoğu aylarda istatistiksel olarak önemsiz bulunmuştur. Yapraklardaki karbonhidrat fraksiyonları üzerine çeşitlerin etkisi anaçlardan daha önemli olmuştur. Örnekleme yapılan tüm aylarda yapraklardaki toplam karbonhidrat içeriği üzerine anaç-kalem kombinasyonunun etkisi önemli bulunmuştur.

Anahtar Kelimeler: Satsuma; Çeşit; Anaç; Karbonhidratlar; Yaprak dokusu

(C) Ankara Üniversitesi Ziraat Fakültesi

\section{Introduction}

Rootstocks have had a substantial role in the development of the citrus industry in the world. Rootstock utilization is necessary for solving both limiting and restricting factors of citrus production (soil, climate, disease, and pests, etc.) and meeting producers and consumers demands such as productivity, earliness, shorter juvenility, fruit quality (Davies \& Albrigo 1998). The researchers have demonstrated that citrus rootstocks have differently influenced the growth and development, including yield, fruit quality, and tolerance to stress caused by biotic and abiotic factors of budded cultivars in relation to ecological conditions (Stenzel et al 2003; Filho et al 2007).

In deciduous trees, the root system is the major storage organ for carbohydrates. In evergreen citrus, the root system may be the major storage organ for carbohydrates, but high concentrations of carbohydrates can also be found in the leaves (Goldschmidt 1999). The crop load inversely effects the accumulation of reserves and under heavy crop load causing depletion of it may cause to tree collapse and the triggering of an alternate bearing habit (Monerri et al 2011). There are correlations between accumulation of carbohydrates and flower formation in some experiments, but carbohydrate levels are not the sole factor regulating citrus flowering (Garcia-Luis \& Guardiola 2000). Although the evidence is still mostly indirect, it may be concluded that the level of carbohydrates is often a major factor limiting fruit set (Monerri et al 2011). The decrease in carbohydrate levels during the flowering and fruit set period, which is accelerated by heavy flowering, shows that reserve carbohydrates are indeed utilized to sustain the early stages of reproductive development. The energy demand during the flowering and fruit set period may be more than the supply of carbohydrates from current photosynthesis and tree reserves. This occurs especially in abundant flowering and heavy initial fruit set. The costs of reproduction require the use of stored reserves in addition to current photosynthate (Goldschmidt 1999).

High levels of starch stored during the fall and carbohydrate status of trees are indicative of their vitality and photosynthetic capacity. It was reported that changes in such patterns could reflect variations in physiological performance and could be useful in understanding the physiology of trees affected by environmental stress (Wong et al 2003). It is important to know carbohydrate reserve status for experiments involving manipulation of the carbon balance of fruit trees (McQueen et al 2004). Annual patterns of carbohydrate storage and mobilization vary among species and genotypes based on growing conditions, growth characteristics, crop load and other factor (Spann et al 2008).

Sour orange (Citrus aurantium L. var. Yerli) has been widely used for citrus production in Turkey. On the other hand, Carrizo and Troyer citranges [Citrus sinensis (L.) Osb. x Poncirus trifoliata (L.) Raf.] are currently the most important citrus rootstocks all over the world, mainly due to their tolerance to tristeza virus (Forner-Giner et al 2003). The effect of these three rootstocks on seasonal carbohydrate 
variability in citrus species is not yet completely clarified. This study was conducted to determine the role of cultivar, rootstock and cultivar-rootstock interaction on seasonal carbohydrate changes in leaf tissues in Eastern Mediterranean Region of Turkey.

\section{Material and Methods}

The experiment was conducted at the experimental farm of Mustafa Kemal University in Dörtyol, Hatay, Turkey $\left(36^{\circ} 09^{\prime} \mathrm{E}, 36^{\circ} 51^{\prime} \mathrm{N}\right.$; $9 \mathrm{~m}$ above the sea level) in the 2010 and 2011 growing seasons. 'Okitsu', 'Clausellina', and 'Silverhill' satsuma cultivars were budded on the sour orange (So), Carrizo (Cc) and Troyer (Tc) citranges. The experimental orchard was established with one year old budded young trees in five replicates with $7 \times 7 \mathrm{~m}$ plots in November 1998 and February 1999.

On a monthly basis leaf samples were collected from the fruitless shoots of each mandarin cultivar trees on each rootstock during the entire year. Leaves were sampled from the summer flush of the previous year, which were about 5-6 months old at January (form January to June), and from the spring flush of the current season, which were about 3-4 months old at July (from July to December). Sampled leaves were decontaminated by washing with a detergent solution, tap water and rinsed with distilled water. Then, samples were dried to a constant mass at 65$70{ }^{\circ} \mathrm{C}$ and homogenized by particle size reduction to $<0.5 \mathrm{~mm}$, then stored at $4{ }^{\circ} \mathrm{C}$ until extraction.

The soluble carbohydrates (fructose, glucose, and sucrose) were analyzed by high-performance liquid chromatography (HPLC) similar to the procedures of Kafkas et al (2007). The sugars were detected using a refractive index detector and quantified by the external standard method. Total sugar and starch contents were determined using the anthrone method with spectrophotometric assay, according to the procedure described by Kaplankiran (1984). Concentrations of total sugar and starch were summed to give an estimate of total non-structural carbohydrate. All carbohydrate results were expressed as glucose equivalents according to dry mass basis (\%).
The carbohydrate data collected in 2010 and 2011 from the leaves of three mandarin cultivars budded on different rootstocks and were subjected to the analysis of variance using GLM procedure of SAS software (SAS Institute Inc., North Carolina, USA). Mean separations were carried out by a Tukey test and assessed at the 5\% significance level.

\section{Results and Discussion}

The results showed that the seasonal changing trends of leaf soluble sugar contents of 3 satsuma cultivars budded on different rootstocks were similar (Figure 1, 2, 3). The sucrose was the predominant soluble sugar in different satsuma cultivars. The sucrose concentrations decreased steadily from maximum concentrations (January) until June for 'Clausellina', and until July for 'Okitsu' and 'Silverhill'. In this period, the sharp decrease in leaf sucrose concentrations of 'Okitsu', 'Clausellina' and 'Silverhill' happened after flowering in April (39.6\%, 39.8\% and 43.1\%, respectively). Accumulation of sucrose in leaves generally started after mid summer and continued until the end of year. During the whole year, the mean leaf sucrose concentrations changed in 'Okitsu' between 1.74\% (Cc) and $1.85 \%(\mathrm{Tc})$, in 'Clausellina' between $1.78 \%$ (Tc) and $2.00 \%$ (So), and in 'Silverhill' between $1.94 \%$ (So) and $2.13 \%(\mathrm{Cc})$. Seasonal pattern of fructose and glucose concentrations were almost similar for all mandarin cultivars. Considering all rootstocks, in dormant period maximum fructose and glucose levels approximated $1.49 \%$ and $1.69 \%$ in 'Okitsu', $1.49 \%$ and $1.70 \%$ in 'Clausellina', and $1.98 \%$ and $1.97 \%$ in 'Silverhill', respectively. Also, the minimum concentrations were $0.23 \%$ for fructose and $0.09 \%$ for glucose in 'Okitsu', and were similar with $0.31 \%$ for both fructose and glucose in 'Clausellina' and 'Silverhill', during July and August. Throughout the entire season, the mean contents of fructose and glucose in leaves were the highest level with $0.81 \%(\mathrm{Cc})$ and $0.69 \%$ (Cc and So) in 'Okitsu', $0.86 \%$ and $0.80 \%$ (So) in 'Clausellina' and $0.86 \%$ (Tc) and $0.88 \%$ (Tc and So) in 'Silverhill'. 


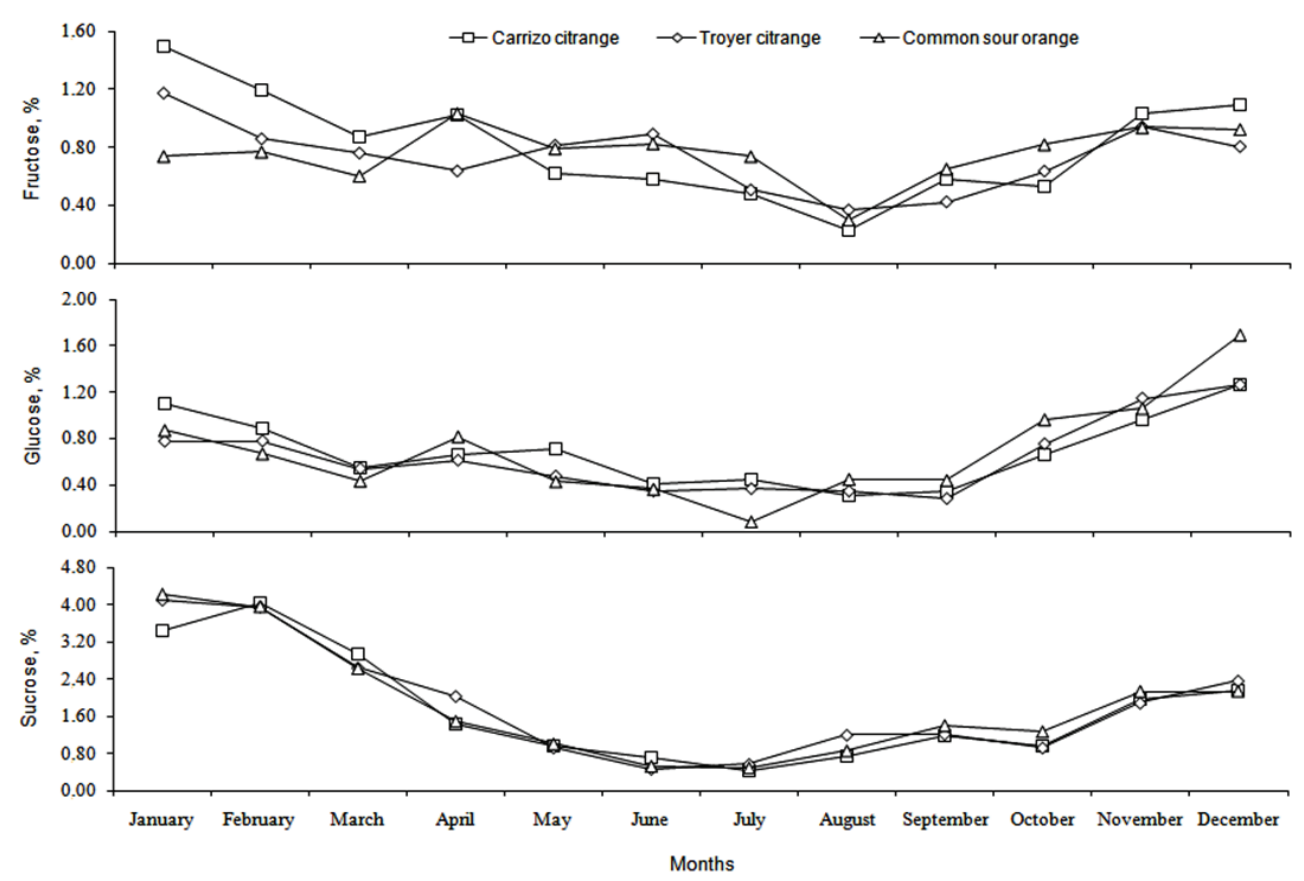

Figure 1- Seasonal variation in soluble sugar content in leaves of 'Okitsu' cultivar budded on different rootstocks

Şekil 1- Farklı anaçlar üzerine aşılı 'Okitsu' çeşidinin yapraklarındaki çözünebilir şeker içeriklerinin aylık değişimi

In this study, the level of sucrose in the leaf tissues of all satsuma cultivars budded on different rootstocks was higher than those of fructose and glucose throughout the entire year. It is well known that sucrose is the major translocated sugar in the most of plants. During the active growing period (from June to August), the photosynthate produced by leaves is not stored but is mobilized and transported as sucrose to various sinks for growth and metabolism (Quick \& Neuhaus 1997).

The total soluble sugar content was high level at dormant period, and remained low level during summer. The sharp decrease in total soluble sugar concentration of leaves occurred in April and May. The cultivars had a significant effect on total soluble sugar concentration of leaves compared to rootstocks. The rootstocks were found to be not significant for total soluble sugar concentration in most of the months. The cultivar $\mathrm{x}$ rootstock interactions was significant on leaf total soluble sugar content within year, but August (Table 1).

In general, the starch level was lower than total soluble sugar level in leaves. The highest leaf starch contents were observed in winter (5.51\%) with the lowest values obtained in late summer $(2.00 \%)$ and early autumn $(1.98 \%)$. The effect of cultivars on leaf starch content was higher than those of both rootstocks and scion-rootstock relation. There was no consistent significant difference in starch content of leaves among rootstocks, except for November (Table 2).

Total carbohydrate concentration of leaves showed a decrease from dormant period to mid or late summer, and then accumulation started until the end of year. In fruit development, a sharp fall in total carbohydrate concentration occurred in April 


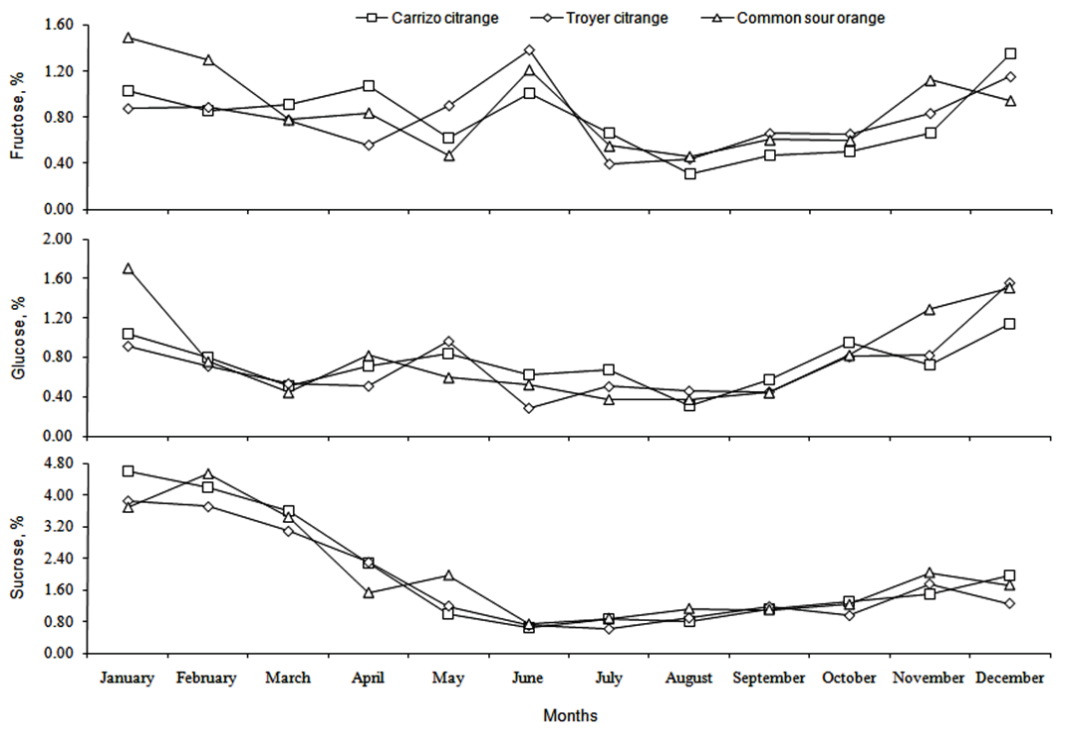

Figure 2- Seasonal variation in soluble sugar content in leaves of 'Clausellina' cultivar budded on different rootstocks

Şekil 2- Farklı anaçlar üzerine aşılı 'Clausellina' çeşidinin yapraklarındaki çözünebilir şeker içeriklerinin aylık değişimi

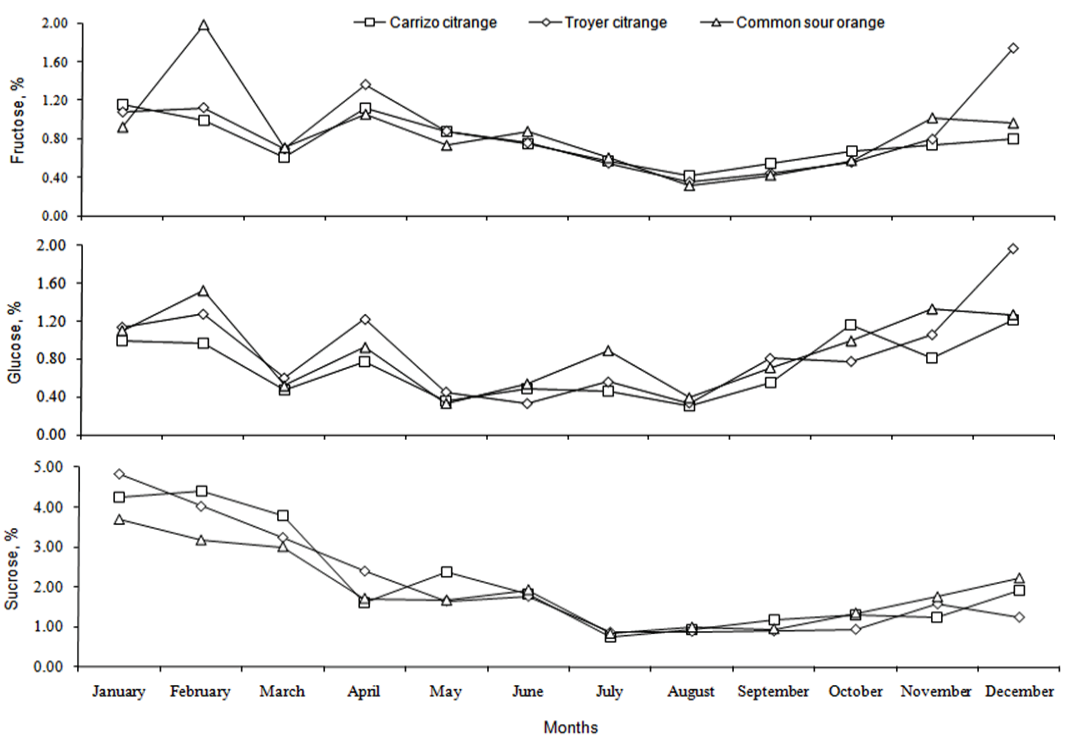

Figure 3- Seasonal variation in soluble sugar content in leaves of 'Silverhill' cultivar budded on different rootstocks

Şekil 3- Farklı anaçlar üzerine aşıll 'Silverhill' çeşidinin yapraklarındaki çözünebilir şeker içeriklerinin aylık değişimi 
Table 1- The effect of cultivar, rootstock and scion-rootstock combination on total soluble sugar content of leaves in different cultivars (\%)

Çizelge 1-Farklı çeşitlerin yapraklarındaki toplam şeker içeriği üzerine çeşit, anaç ve çeşit-anaç kombinasyonunun etkisi (\%)

\begin{tabular}{|c|c|c|c|c|c|c|c|c|c|c|c|c|c|}
\hline \multirow{2}{*}{ Source } & \multicolumn{12}{|c|}{ Months } & \multirow{2}{*}{ Mean } \\
\hline & 1 & 2 & 3 & 4 & 5 & 6 & 7 & 8 & 9 & 10 & 11 & 12 & \\
\hline \multicolumn{14}{|l|}{ Cultivars } \\
\hline Okitsu & 8.10 & 7.24 & 6.03 & 4.81 & 3.10 & 2.76 & 2.24 & 2.82 & 3.76 & 4.38 & 6.95 & 7.77 & 5.00 \\
\hline Clausellina & 8.60 & 7.77 & 6.84 & 5.74 & 4.55 & 3.72 & 3.07 & 2.88 & 4.00 & 4.22 & 6.19 & 7.63 & 5.43 \\
\hline Silverhill & 8.48 & 8.10 & 7.34 & 6.21 & 5.41 & 4.25 & 3.20 & 2.79 & 3.68 & 4.47 & 5.90 & 7.85 & 5.64 \\
\hline HSD (5\%) & ns & 0.52 & 0.89 & 0.55 & 0.41 & 0.36 & 0.53 & ns & ns & ns & 0.65 & ns & - \\
\hline \multicolumn{14}{|l|}{ Rootstocks } \\
\hline Carrizo citr. & 8.86 & 7.83 & 7.10 & 5.47 & 4.23 & 3.57 & 3.06 & 2.51 & 3.91 & 4.73 & 6.21 & 7.89 & 5.45 \\
\hline Troyer citr. & 8.02 & 7.45 & 7.01 & 5.90 & 4.57 & 3.47 & 2.59 & 3.11 & 3.82 & 3.80 & 6.17 & 7.44 & 5.28 \\
\hline Sour orange & 8.31 & 7.83 & 6.10 & 5.39 & 4.25 & 3.69 & 2.87 & 2.87 & 3.71 & 4.55 & 6.65 & 7.91 & 5.34 \\
\hline $\operatorname{HSD}(5 \%)$ & 0.67 & ns & 0.87 & ns & $\mathrm{ns}$ & ns & $\mathrm{ns}$ & 0.43 & $\mathrm{~ns}$ & 0.77 & $\mathrm{~ns}$ & $\mathrm{~ns}$ & - \\
\hline \multicolumn{14}{|c|}{ Scion-rootstock combination } \\
\hline \multicolumn{14}{|c|}{ Okitsu } \\
\hline Carrizo cit. & 8.68 & 7.51 & 5.95 & 4.36 & 3.06 & 2.86 & 2.41 & 2.33 & 3.62 & 3.75 & 6.92 & 7.52 & 4.91 \\
\hline Troyer citr. & 8.16 & 7.10 & 6.82 & 5.07 & 3.11 & 2.63 & 2.16 & 3.35 & 3.30 & 4.13 & 6.86 & 7.60 & 5.02 \\
\hline Sour orang. & 7.47 & 7.13 & 5.31 & 5.00 & 3.12 & 2.78 & 2.17 & 2.78 & 4.37 & 5.26 & 7.06 & 8.18 & 5.05 \\
\hline \multicolumn{14}{|l|}{ Clausellina } \\
\hline Carrizo cit. & 9.26 & 7.85 & 7.06 & 5.97 & 4.17 & 3.72 & 3.77 & 2.52 & 3.96 & 4.98 & 6.59 & 8.58 & 5.70 \\
\hline Troyer citr. & 7.68 & 7.14 & 6.76 & 5.97 & 4.98 & 3.59 & 2.61 & 3.13 & 4.36 & 3.56 & 5.75 & 6.35 & 5.16 \\
\hline Sour orang. & 8.87 & 8.33 & 6.71 & 5.28 & 4.50 & 3.84 & 2.84 & 2.98 & 3.69 & 4.11 & 6.24 & 7.96 & 5.44 \\
\hline \multicolumn{14}{|l|}{ Silverhill } \\
\hline Carrizo cit. & 8.64 & 8.13 & 8.30 & 6.09 & 5.46 & 4.11 & 2.99 & 2.68 & 4.15 & 5.45 & 5.12 & 7.56 & 5.72 \\
\hline Troyer citr. & 8.21 & 8.12 & 7.45 & 6.67 & 5.63 & 4.18 & 3.00 & 2.85 & 3.82 & 3.70 & 5.92 & 8.39 & 5.66 \\
\hline Sour orang. & 8.60 & 8.05 & 6.27 & 5.89 & 5.13 & 4.46 & 3.60 & 2.84 & 3.06 & 4.27 & 6.66 & 7.59 & 5.53 \\
\hline $\operatorname{HSD}(5 \%)$ & 1.23 & 1.01 & 1.34 & 1.04 & 0.83 & 0.91 & 0.91 & ns & 0.82 & 1.12 & 1.09 & 0.84 & - \\
\hline
\end{tabular}

ns, non-significant

Table 2- The effect of cultivar, rootstock and scion-rootstock combination on starch content of leaves in different cultivars $(\%)$

Çizelge 2- Farkl çeşitlerin yapraklarındaki nişasta içeriği üzerine çeşit, anaç ve çeşit-anaç kombinasyonunun etkisi (\%)

\begin{tabular}{|c|c|c|c|c|c|c|c|c|c|c|c|c|c|}
\hline \multirow[b]{2}{*}{ Source } & \multicolumn{12}{|c|}{ Months } & \multirow{2}{*}{ Mean } \\
\hline & 1 & 2 & 3 & 4 & 5 & 6 & 7 & 8 & 9 & 10 & 11 & 12 & \\
\hline \multicolumn{14}{|l|}{ Cultivars } \\
\hline Okitsu & 4.46 & 5.13 & 5.02 & 3.15 & 2.18 & 2.13 & 2.06 & 1.76 & 1.91 & 2.47 & 3.07 & 4.60 & 3.16 \\
\hline Clausellina & 4.55 & 5.42 & 5.80 & 4.04 & 2.88 & 2.32 & 2.41 & 2.01 & 1.90 & 2.54 & 3.82 & 5.02 & 3.56 \\
\hline Silverhill & 4.73 & 5.39 & 5.71 & 4.10 & 3.29 & 2.91 & 2.62 & 2.24 & 2.14 & 2.67 & 3.72 & 5.00 & 3.71 \\
\hline $\operatorname{HSD}(5 \%)$ & ns & ns & 0.53 & 0.50 & 0.47 & 0.63 & 0.40 & 0.42 & ns & ns & 0.46 & ns & - \\
\hline \multicolumn{14}{|l|}{ Rootstocks } \\
\hline Carrizo citr. & 4.76 & 5.45 & 5.32 & 3.80 & 2.65 & 2.46 & 2.28 & 1.99 & 1.91 & 2.54 & 3.84 & 5.03 & 3.50 \\
\hline Troyer citr. & 4.42 & 5.07 & 5.61 & 3.69 & 2.86 & 2.50 & 2.36 & 1.92 & 2.02 & 2.50 & 3.27 & 4.67 & 3.41 \\
\hline Sour orange & 4.57 & 5.42 & 5.60 & 3.80 & 2.84 & 2.39 & 2.45 & 2.09 & 2.00 & 2.63 & 3.49 & 4.93 & 3.52 \\
\hline $\operatorname{HSD}(5 \%)$ & ns & ns & ns & ns & ns & ns & ns & ns & ns & ns & 0.54 & ns & - \\
\hline \multicolumn{14}{|c|}{ Scion-rootstock combination } \\
\hline Carrizo cit. & 4.61 & 5.19 & 4.72 & 3.12 & 2.02 & 2.03 & 1.78 & 1.75 & 1.68 & 2.32 & 3.28 & 4.80 & 3.11 \\
\hline Troyer citr. & 4.46 & 4.78 & 5.28 & 2.96 & 1.96 & 2.40 & 2.12 & 1.56 & 1.95 & 2.52 & 3.00 & 4.22 & 3.10 \\
\hline Sour orang. & 4.31 & 5.41 & 5.05 & 3.35 & 2.54 & 1.95 & 2.29 & 1.97 & 2.09 & 2.56 & 2.95 & 4.79 & 3.27 \\
\hline Clausellina & & & & & & & & & & & & & \\
\hline Carrizo cit. & 4.88 & 5.40 & 5.52 & 3.77 & 2.84 & 2.56 & 2.50 & 1.87 & 2.08 & 2.64 & 4.08 & 5.12 & 3.60 \\
\hline Troyer citr. & 4.17 & 5.28 & 5.58 & 3.95 & 3.17 & 2.16 & 2.15 & 2.11 & 2.04 & 2.43 & 3.36 & 4.81 & 3.43 \\
\hline Sour orang. & 4.62 & 5.59 & 6.30 & 4.40 & 2.64 & 2.25 & 2.60 & 2.05 & 1.57 & 2.54 & 4.02 & 5.12 & 3.64 \\
\hline Silverhill & & & & & & & & & & & & & \\
\hline Carrizo cit. & 4.80 & 5.75 & 5.71 & 4.50 & 3.09 & 2.81 & 2.56 & 2.36 & 1.98 & 2.65 & 4.18 & 5.15 & 3.80 \\
\hline Troyer citr. & 4.62 & 5.14 & 5.98 & 4.15 & 3.44 & 2.94 & 2.81 & 2.10 & 2.08 & 2.56 & 3.46 & 4.98 & 3.69 \\
\hline Sour orang. & 4.77 & 5.28 & 5.44 & 3.64 & 3.34 & 2.97 & 2.47 & 2.25 & 2.34 & 2.80 & 3.52 & 4.86 & 3.64 \\
\hline $\operatorname{HSD}(5 \%)$ & ns & ns & 1.14 & 1.02 & 1.09 & ns & 0.92 & ns & ns & ns & 0.83 & ns & - \\
\hline
\end{tabular}


and May with 27.9-33.8\% for 'Okitsu', 22.6-24.0\% for 'Clausellina' and, $21.0-15.6 \%$ for 'Silverhill'. The amounts of total carbohydrate reduced in 25.4$25.8 \%, 24.1-22.5 \%$ and $21.5-22.9 \%$ rates for $\mathrm{Cc}$, Tc and So, respectively, in April and May as compared to the previous month. The effect of cultivars on total carbohydrate concentration in leaves was almost similar with rootstocks. Rootstocks had no significant effect on leaf total carbohydrate content, but January, August, October and November. The scion-rootstock combination was significant in total carbohydrate concentration of leaves in investigated all months (Table 3).
The reported seasonal patterns of carbohydrate in citrus trees (Goldschmidt 1999; Monerri et al 2011) were similar to those seen in satsuma trees grown in Eastern Mediterranean conditions. In this study, the carbohydrate content of the leaves in investigated all satsuma cultivars budded on different rootstocks continuously decreased from January to mid or late-summer, then gradually began to rise during autumn and winter. The carbohydrate concentration of leaves returned to similar levels over winter. The concentration of carbohydrate in leaves declined sharply in April and May. This may suggest that these

Table 3- The effect of cultivar, rootstock and scion-rootstock combination on total carbohydrate content of leaves in different cultivars (\%)

Çizelge 3- Farklı çeşitlerin yapraklarındaki toplam karbonhidrat içeriği üzerine çeşit, anaç ve çeşit-anaç kombinasyonunun etkisi (\%)

\begin{tabular}{|c|c|c|c|c|c|c|c|c|c|c|c|c|c|}
\hline \multirow{2}{*}{ Source } & \multicolumn{12}{|c|}{ Months } & \multirow{2}{*}{ Mean } \\
\hline & 1 & 2 & 3 & 4 & 5 & 6 & 7 & 8 & 9 & 10 & 11 & 12 & \\
\hline \multicolumn{14}{|l|}{ Cultivars } \\
\hline Okitsu & 12.57 & 12.37 & 11.04 & 7.96 & 5.27 & 4.88 & 4.31 & 4.58 & 5.67 & 6.85 & 10.02 & 12.37 & 8.16 \\
\hline Clausellina & 13.16 & 13.20 & 12.64 & 9.78 & 7.43 & 6.04 & 5.49 & 4.88 & 5.90 & 6.75 & 10.01 & 12.65 & 8.99 \\
\hline Silverhill & 13.22 & 13.49 & 13.05 & 10.31 & 8.70 & 7.16 & 5.81 & 5.03 & 5.81 & 7.14 & 9.62 & 12.84 & 9.35 \\
\hline HSD (5\%) & ns & 0.67 & 1.07 & 0.69 & 0.62 & 0.57 & 0.57 & ns & ns & ns & ns & $\mathrm{ns}$ & - \\
\hline \multicolumn{14}{|l|}{ Rootstocks } \\
\hline Carrizo citr. & 13.62 & 13.28 & 12.42 & 9.27 & 6.88 & 6.03 & 5.34 & 4.50 & 5.82 & 7.26 & 10.05 & 12.91 & 8.95 \\
\hline Troyer citr. & 12.44 & 12.52 & 12.63 & 9.59 & 7.43 & 5.97 & 4.95 & 5.03 & 5.85 & 6.30 & 9.45 & 12.11 & 8.69 \\
\hline Sour orange & 12.88 & 13.26 & 11.70 & 9.19 & 7.09 & 6.08 & 5.32 & 4.96 & 5.71 & 7.18 & 10.14 & 12.84 & 8.86 \\
\hline HSD (5\%) & 0.80 & ns & ns & ns & $\mathrm{ns}$ & ns & ns & 0.44 & ns & 0.84 & 0.58 & ns & - \\
\hline \multicolumn{14}{|c|}{ Scion-rootstock combination } \\
\hline \multicolumn{14}{|l|}{ Okitsu } \\
\hline Carrizo cit. & 13.29 & 12.70 & 10.66 & 7.48 & 5.08 & 4.89 & 4.19 & 4.08 & 5.29 & 6.08 & 10.19 & 12.32 & 8.02 \\
\hline Troyer citr. & 12.62 & 11.88 & 12.10 & 8.04 & 5.08 & 5.03 & 4.28 & 4.91 & 5.25 & 6.65 & 9.86 & 11.81 & 8.13 \\
\hline Sour orang. & 11.78 & 12.53 & 10.36 & 8.35 & 5.66 & 4.73 & 4.46 & 4.75 & 6.46 & 7.81 & 10.01 & 12.98 & 8.32 \\
\hline \multicolumn{14}{|l|}{ Clausellina } \\
\hline Carrizo cit. & 14.13 & 13.26 & 12.57 & 9.74 & 7.01 & 6.28 & 6.27 & 4.39 & 6.04 & 7.62 & 10.66 & 13.71 & 9.31 \\
\hline Troyer citr. & 11.85 & 12.42 & 12.34 & 9.92 & 8.15 & 5.75 & 4.76 & 5.23 & 6.40 & 5.99 & 9.10 & 11.16 & 8.59 \\
\hline Sour orang. & 13.49 & 13.91 & 13.01 & 9.68 & 7.14 & 6.09 & 5.44 & 5.03 & 5.27 & 6.65 & 10.25 & 13.08 & 9.09 \\
\hline \multicolumn{14}{|l|}{ Silverhill } \\
\hline Carrizo cit. & 13.44 & 13.88 & 14.01 & 10.59 & 8.55 & 6.92 & 5.55 & 5.04 & 6.14 & 8.10 & 9.30 & 12.71 & 9.52 \\
\hline Troyer citr. & 12.84 & 13.27 & 13.43 & 10.82 & 9.07 & 7.12 & 5.81 & 4.95 & 5.89 & 6.26 & 9.38 & 13.36 & 9.35 \\
\hline Sour orang. & 13.37 & 13.32 & 11.72 & 9.53 & 8.47 & 7.43 & 6.07 & 5.09 & 5.40 & 7.07 & 10.17 & 12.45 & 9.18 \\
\hline HSD (5\%) & 1.11 & 1.08 & 1.57 & 1.37 & 1.17 & 1.46 & 0.86 & 0.81 & 1.16 & 1.12 & 0.93 & 1.05 & - \\
\hline
\end{tabular}


carbohydrates were transported from the leaves to support active growth such as bud break, primary root growth, shoot expansion, leaf emergence and enlargement, flowering, and fruit and seed set (Goodman et al 1990). Carbohydrates mobilized during the spring flush of growth. The seasonal carbohydrate profile of the leaves of satsuma cultivars showed seasonal patterns that closely relate to seasonal changes in phenological and physiological activities.

Under Eastern Mediterranean conditions, in citrus bud break occurred at early spring as from the second half of March and then vegetative development such as shoot expansion, young leaf and root growth began. Citrus flowering happened primarily during the spring following the inductive winter season. In citrus, anthesis occurred as from mid April after the flower bud induction and differentiation of floral organs processes, which begins at the first stages of bud swelling and sprouting. Thus, carbohydrate reserves are used primarily for vegetative growth. Spann et al (2008) reported that the extent to which reserves are used to support vegetative versus reproductive growth early in the season depends on their temporal relationship with growth. Nzima et al (1997) showed that developing fruits serve as competitive sinks for available metabolites. During the period of fruit abscission (May and June), in which competition for carbohydrates is considered to be a limiting factor for fruit retention, fruit nutrition is supported by current photosynthesis and stored reserves (Goldschmidt 1999).

In other reports it has been noticed that different rootstocks affect citrus tree physiology especially net photosynthetic rates (Gonzalez-Mas et al 2009; Sheng et al 2009). However, there is not sufficient study about the effect of rootstocks on accumulation of carbohydrate changes in citrus plant tissues. In this study, there was no consistent significant difference in starch content of leaves among rootstocks, except for November, and the rootstocks were found to be not significant for total soluble sugar and carbohydrate concentration in most of the months. It has been reported that the soluble sugar, starch and total carbohydrate content of 'Washington Navel' leaves (Yildirim 2003) and 'Navelina' roots (Lliso et al 2004) was affected by the rootstocks, but that the effect of rootstocks on soluble sugar and starch content of 'Marsh Seedless' leaves (Acikalin et al 2009) was not found in most of the samples time. The scion-rootstock combination had a higher effect on carbohydrate content of leaves in investigated all months, except for starch, than those of both cultivar and rootstock. This finding is supported that rootstock and scion have affected each other in terms of activities for physiological events. Likewise, the effect of rootstocks on tree canopy volume changed according to cultivars in this study (not show data). For example, So rootstock in 'Okitsu', Tc rootstock in 'Clausellina', and both So and Tc rootstocks in 'Silverhill' obtained lower canopy volume than those of used in study other rootstocks. However, the mean carbohydrate concentration of leaves in 'Okitsu' budded on So rootstock, which is low yield and short shoot, was higher than those of $\mathrm{Cc}$ and $\mathrm{Tc}$ rootstocks. Also, in June and July carbohydrate loss of leaves in 'Clausellina' budded on Tc rootstock, which is high fruit set after June drop, was higher than those on $\mathrm{Cc}$ and So rootstocks as compared to the previous month. But, the differences in carbohydrate content of leaves in 'Silverhill' among rootstocks were not related to crop load.

\section{Conclusions}

This investigation indicated that there was carbohydrate loss largely in the vegetative and generative development phases in satsuma cultivars budded on different rootstocks. The carbohydrate production and accumulation in satsuma trees should be increased at the previous year for using next spring. The rootstock used should be considered at fertilization program because of the citrus rootstocks have different abilities to utilize plant nutrient elements. In addition, satsuma trees should not have problems of nutrients especially in the first months of the growth. 


\section{Acknowledgements}

We would like to thank for financial support from the Scientific Research Projects Coordination Unit of Mustafa Kemal University (Project number: 1001 M 0102).

\section{References}

Acikalin E C, Pekmezci M \& Yesiloglu T (2009). The effects of local sour orange, Carrizo and Troyer citrange rootstocks on carbohydrate contents and seasonal changes in leaves of Marsh Seedless variety grown in Antalya. Tarim Bilimleri Dergisi-Journal of Agricultural Science 15(3): 224-230

Davies F S \& Albrigo L G (1998). Citrus. CAB International, Wallingford, Oxon, UK

Filho F A A M, Espinoza-Nunez E, Stuchi E S \& Ortega E M M (2007). Plant growth, yield, and fruit quality of 'Fallglo' and 'Sunburst' mandarin on four rootstocks. Scientia Horticulture 114(1): 45-49

Forner-Giner M A, Forner J B \& Alcaide A (2003). Forner-alcaide 5 and Forner-alcaide 13: Two new citrus rootstocks released in Spain. HortScience 38(4): $629-630$

Garcia-Luis A \& Guardiola J L (2000). Influence of citrus tree internal factors and climatic effects on flowering. In: Ninth Meeting of the International Citrus Congress, Orlando, USA, pp. 292-295

Goldschmidt E E (1999). Carbohydrate supply as a critical factor for citrus fruit development and productivity. HortScience 34(6): 1020-1024

Gonzalez-Mas M C, Llosa M J, Quijano A \& Forner-Giner M A (2009). Rootstock effects on leaf photosynthesis in 'Navelina' trees grown in calcareous soil. HortScience 44: 280-283

Goodman R M, Yawney H W \& Tubbs C H (1990). Sugar maple (Acer saccharum Marsh.). (Ed: R M Burns; B H Honkala) Silvics of North America, United States Department Agriculture, Agricultural Handbook, USA, pp. 78-91

Kafkas E, Kosar M, Paydas S, Kafkas S \& Baser K H C (2007). Quality characteristics of strawberry genotypes at different maturation stages. Food Chemistry 100(3): 1229-1236

Kaplankiran M (1984). The relationships between citrus rootstocks growth and phytohormone, minerals and carbohydrate content. $\mathrm{PhD}$ Thesis, Cukurova University (Unpublished), Turkey

Lliso I, Forner J B \& Talon M (2004). The dwarfing mechanism of citrus rootstocks F \& A 418 and \#23 is related to competition between vegetative and reproductive growth. Tree Physiology 24(2): 225-232

McQueen J C, Minchin P E H \& Silvester W B (2004). Changes in non-structural carbohydrate concentration in 1-year-old shoots of 'Braeburn' apple (Malus domestica) over two consecutive years. New Zealand Journal of Crop and Horticultural Science 32(3): 319-323

Monerri C, Fortunato-Almeida A, Molina R V, Nebauer S G, Garcia-Luis A \& Guardiola J L (2011). Relation of carbohydrate reserves with the forthcoming crop, flower formation and photosynthetic rate, in the alternate bearing 'Salustiana' sweet orange (Citrus sinensis L.). Scientia Horticulture 129(1): 71-78

Nzima M D S, Martin G C \& Nishijima C (1997). Seasonal changes in total nonstructural carbohydrate within branches and roots of naturally off and on 'Kerman' pistachio trees. Journal of American Society for Horticutural Science 122(6): 856-862

Quick W P \& Neuhaus H E (1997). The regulation and control of photosynthetic carbon assimilation. (Ed: C H Foyer; W P Quick), A Molecular Approach to Primary Metabolism in Higher Plants, Taylor and Frances, Bristol, pp. 41-62

Sheng O, Song S, Peng S \& Deng X (2009). The effects of low boron on growth, gas exchange, boron concentration and distribution of 'Newhall' navel orange (Citrus sinensis Osb.) plants grafted on two rootstocks. Scientia Horticulturae 121(3): 278-283

Spann T M, Bede R H \& Dejong T M (2008). Seasonal carbohydrate storage and mobilization in bearing and non-bearing pistachio (Pistacia vera) trees. Tree Physiology 28(2): 207-213

Stenzel N M C, Neves, C S V J, Gomes J C \& Medina C C (2003). Performance of 'Ponkan' mandarin on seven rootstocks in Southern Brazil. HortScience 38(2): 176-178

Wong B L, Baggett K L \& Rye A H (2003). Seasonal patterns of reserve and soluble carbohydrates in mature sugar maple (Acer saccharum). Canadian Journal of Botany 81(8): 780-788

Yildirim B (2003). The relationship between productivity and carbohydrate levels in Washington Navel oranges grafted on different rootstocks. PhD Thesis, Cukurova University (Unpublished), Turkey 